\title{
Деньги Тувинской Народной Республики в коллекциях Национального музея Тувы
}

\author{
Марианна М.-Б. Харунова
}

Тувинский институт комплексного освоения природных ресурсов СО РАН, Российская Федерация, Рамиль Ш. Харунов

Улан-Баторский филиал Российского экономического университета

\author{
им. Г. В. Плеханова, Монголия,
}

\section{Чейнеш О. Санчай}

Национальный музей им. Алдан-Маадыр Республики Тыва, Российская Федерация

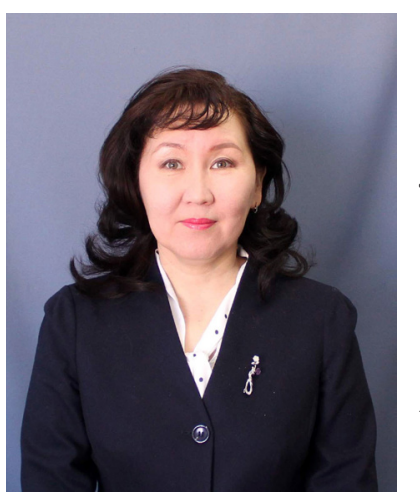

Национальный музей им. Алдан-Маадыр Республики Тыва является хранителем более 1000 единиц денежных знаков различных государств и правительств начала ХХ века. $B$ статье рассматривается денежная коллекция музея периода Тувинской Народной Республики (ТНР). Основными дарителями ценных бумаг, денежных купюр и монет являлись жители республики.

На примере нескольких коллекций прослежена история денежной реформы ТНР. Так, коллекция 1954 г. позволяет познакомиться с историей введения тувинской национальной валюты - акша 1935 и 1940 годов и особенностями каждого из этих двух выпусков. В 1955 г. в музее появились монеты ТНР образца 1934 г. достоинством в 3, 5, 10, 15 коп., которые были в денежном обращении страны до момента вхождения ТНР в состав СССР. В 1956 г. фонды музея пополнились предметами личной коллекции Салчака Тока, партийного руководителя республики (1932-1973). Это были не только тувинские акша, но и боны - денежные купюры 1925, 1926, 1928 годов со штампом ТНР. Они олицетворяют собой переходный этап денежной реформы в Туве. В 1959 г. в дар музею поступили госу-

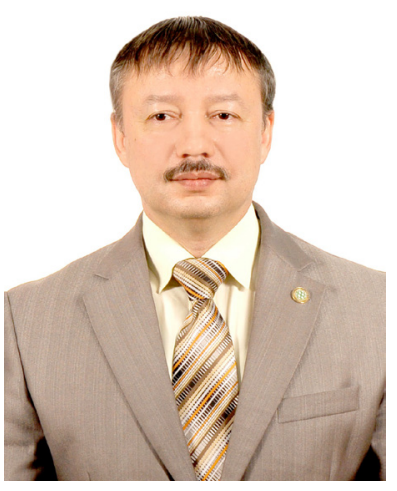
дарственные кредитные билеты ццарской России (боны) 1898 г. - 1 руб., 1905 г. - 3 руб., 1909 г. - 5 и 10 руб. Эти деньги являются свидетельством одного из первых этапов денежной реформы, реализованного Министерством финансов ТНР в 1923 г.

Денежная коллекция Национального музея Тувы является исключительно ценным источником по изучению вопросов экономического развития ТНР. Благодаря сохранившимся образцам мы можем получить достоверную информацию о специфике формирования финансовой системы ТНР, политических деятелях, участвовавших в реализации экономических реформ, о влиянии СССР на социально-экономическое развитие Тувы в первой половине ХХ века.

Ключевые слова: Национальный музей Тувы; музейная коллекция; история Тувы; Тувинская Народная Республика; Салчак Калбакхорекович Тока; денежная реформа; национальная валюта; акша; денежное обращение; советский рубль; боны

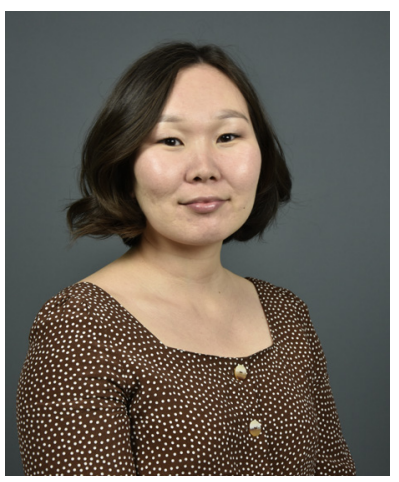

Для цитирования:

Харунова М. М.-Б., Харунов Р. Ш., Санчай Ч. О. Деньги Тувинской Народной Республики в коллекциях Национального музея Тувы [Электронный ресурс] // Новые исследования Тувы. 2019, № 2. URL: https://nit.tuva.asia/nit/article/view/849 (дата обращения: дд.мм.гг.). DOI: 10.25178/nit.2019.2.9

Харунова Марианна Монге-Байыровна - кандидат исторических наук, ведущий научный сотрудник лаборатории математического моделирования Тувинского института комплексного освоения природных ресурсов СО РАН. Адрес: 667007, Россия, г. Кызыл, ул. Интернациональная, д. 117А. Тел.: +7 (394-22) 6-62-18. Эл. адрес: ondar18@ mail.ru ORCID ID: 0000-0002-9011-2262

Харунов Рамиль Шатмуратович - кандидат исторических наук, доцент междисциплинарной кафедры Улан-Баторского филиала Российского экономического университета им. Г. В. Плеханова. Адрес: 210351, Монголия, г. Улан-Батор, проспект Мира, д. 131. Тел.: (+976) 11-450-679. Эл. адрес: ramar33@mail. ru ORCID ID: 0000-0001-7940-5972

Санчай Чейнеш Орлановна - экскурсовод отдела культурно-образовательной работы Национального музея им. Алдан-Маадыр Республики Тыва. Адрес: 667000, Россия, г. Кызыл, ул. Титова, д. 30. Тел.: +7 (923) 269-52-01. Эл. адрес: neshsunchai@gmail.com ORCID ID:0000-0002-3777-8743

Kharunova Marianna Monge-Bairovna, Candidate of History, Leading research fellow, Laboratory of regional economics, Tuvan Institute for Exploration of Natural Resources, Siberian Branch, Russian Academy of Sciences. Postal address: 117A Internatsionalnaya St., 667010 Kyzyl, Russian Federation. Tel.: +7 (913) 356-10-73. E-mail: Ondar18@mail.ru

Kharunov Ramil Shatmuratovich, Candidate of History, Associate Professor, Interdisciplinary Department, Ulan Bator Branch, Plekhanov Russian University of Economics. Postal address: 131 Peace Avenue, Ulan Bator, 210351 Mongolia. Tel.: (+976) 11-450-679. E-mail: ramar33@mail.ru

Sanchai Cheinesh Orlanovna, Guide, Department of Cultural and Educational Work, Aldan-Maadyr National Museum of the Republic of Tuva. Postal address: 30 Titov St., 667000 Kyzyl, Russian Federation. Tel.: +7 (923) 269-52-01. E-mail: neshsunchai@gmail.com 


\title{
Money of the People's Republic of Tuva in the collections of the Aldan-Maadyr National Museum of Tuva
}

\author{
Marianna M.-B. Kharunova \\ Tuvan Institute for Exploration of Natural Resources, Siberian Branch of the Russian Academy of Sciences, \\ Russian Federation, \\ Ramil Sh. Kharunov \\ Ulan Bator branch, Plekhanov Russian University of Economics, Mongolia, \\ Cheinesh O. Sanchai \\ Aldan-Maadyr National Museum of the Republic of Tuva, Russian Federation
}

The Aldan-Maadyr National Museum has more than 1,000 coins and banknotes issued by various states and governments of the early 20th century. This article describes the museum's holding of monetary units issued by the People's Republic of Tuva. As shown in the museum accessory books, banknotes/coins and securities came mostly as donations by local residents.

Our study of several such collections preserved at the museum allowed us to trace the history of monetary reforms in the PRT. For instance, the 1954 collection sheds light on the history of Tuva's currency, the aksha, issued in 1935 and 1940 and the features of both respective issues. In 1955, the museum exhibited the 3, 5, 10 and 15-kopeck PRT coins minted in 1934 and remaining in circulation prior to the accession of the PRT into the USSR. In 1956, the museum acquired Salchak Toka's personal collection. Its owner was the leader of the republic's Communist party from 1932 to 1973. His collection included not only the Tuvan aksha, but also the bonds - banknotes issued in 1925, 1926, and 1928 bearing the PRT stamp. The latter are an evidence of the transition phase in Tuva's monetary reform. In 1959, the museum was presented with a collection of Czarist Russia bankbills of 1898 (1 ruble), 1905 (3 rubles), and 1909 (5 and 10 rubles). They were used at one of the first stages of monetary reform implemented by Ministry of Finance of the PRT in 1923.

The collection of monetary units of National Museum of Tuva is a highly valuable source for studying the republic's economic development. The surviving samples of monetary units issued in 1935 and 1940, as well as the stamped bills which had been in circulation in earlier periods, allow us to obtain reliable details that may provide insight into characteristic aspects of the rise of the financial system of PRT, political leaders who implemented economic reforms, and the involvement of the USSR in social and economic development of Tuva in the early twentieth century.

Keywords: National Museum of Tuva; museum collection; history of Tuva; People's Republic of Tuva; Salchak Kalbakhorekovich Toka; currency reform; national currency; aksha; monetary circulation; Soviet ruble; bonds

\author{
For citation: \\ Kharunova M. M.-B., Kharunov R. Sh. and Sanchai Ch. O. Money of the People's Republic of Tuva in the collections of \\ the Aldan-Maadyr National Museum of Tuva. The New Research of Tuva. 2019, № 2. URL: https://nit.tuva.asia/nit/article/ \\ view/849 (access date ... ). DOI: 10.25178/nit.2019.2.9
}

\section{Введение}

Монеты и бумажные деньги, с одной стороны, являются источником изучения экономической истории государств, истории товарно-денежных отношений, с другой стороны - это предметы искусства. Принято считать, что коллекционирование монет началось в XIV-XV вв. в Италии, и далее распространилось по другим странам Европы. В России исследования в области нумизматики сосредоточены в главных музеях, располагающих крупнейшими коллекциями монет: в Эрмитаже (г. СанктПетербург), Государственном Историческом музее (г. Москва) и других, в том числе в музеях субъектов Российской Федерации, а также в исторических, археологических институтах РАН.

В Туве самая уникальная коллекция денег - более 1000 единиц денежных знаков различных государств и правительств, хранится в фондах Национального музея им. Алдан-Маадыр Республики Тыва (далее - НМ РТ). Абсолютное большинство из них имело хождение в виде средств денежного обращения в Урянхайском крае в начале XX в. и далее в период становления ТНР (Бичелдей, 2009: 18).

Вопросы развития финансово-денежной системы ТНР рассматривались исследователями в контексте общих процессов социально-экономического развития республики, а также в рамках отдельных публикаций по данной теме. К числу первых можно отнести труды В. М. Иезуитова (Иезуитов, 1956: 208), Ю. Л. Аранчына (Аранчын, 1982: 184), а также второй том «Истории Тувы» (История, 2007: 430), в которых представлено политическое, социально-экономическое и культурное развитие Тувы с феодального прошлого до вхождения в состав СССР. В работах изучены предпосылки становления товарно-денежных отношений в Туве, специфика развития государственной системы ТНР, в том числе в экономической 
сфере. Особо отмечается роль правительства ТНР и деятельность Тувинского торгово-промышленного банка в введении тувинской национальной валюты акша ${ }^{1}$ и регулировании финансово-кредитной системы республики.

О зарождении и развитии финансово-кредитной системы ТНР и ее государственном бюджете писал Л. И. Тульчинский. Помимо вопросов государственного страхования, сберегательного дела и налоговой политики, им затронут вопрос о денежных знаках и проблемах денежного обращения ТНР в 20-30 гг. ХХ в. (Тульчинский, 1961: 269).

Более подробно проблему денежного обращения в ТНР исследовал В. А. Копеел. Им рассмотрены вопросы реализации денежной реформы, ее предпосылки и последствия, экономическая политика государства, курс акша в разные годы, особенности первого и второго выпуска акша. (Копеел, 1981: 81).

Современные исследователи также не обходят вниманием эту тему. Предыстория формирования и функционирования денежной системы страны в 1925-1940 гг. по материалам фондов НМ РТ рассмотрена К. А. Бичелдеем. Автор прилагает общее описание параметров монет и бумажных денег ТНР первого и второго выпусков, их культурное и историческое значение. (Бичелдей, 2009: 18).

Также описание каждого выпуска акша: материал, цвета, рисунок, типы печати, номиналы, водяные знаки, тираж и общая сумма каждого выпуска рассмотрены А. Я. Ананьиным и Г. И. Роговым (Ананьин, Рогов, 2014: 134).

В данной статье мы рассмотрим музейную коллекцию, представляющую особенную ценность деньги периода Тувинской Народной Республики (далее - ТНР) - акша. На примере сохранившихся уникальных денежных купюр и монет раскроем специфику реализации денежной реформы и ее основные этапы. Все фотографии коллекции денежных фондов, используемые в статье, любезно предоставлены администрацией НМ РТ и выполнены фотографом А. Д. Куулар.

Кроме музейной коллекции нами в работе над статьей использованы материалы фондов Государственного Архива Республики Тыва (ГА РТ. Ф.1, оп. 2, д. 232, л. 1).

Деньги ТНР - акша (бумажные деньги) и монеты - начали поступать в фонды музея с 1954 г. и, как свидетельствуют записи книг поступлений, последнее пополнение датировано 2013 г.

Для хранения денежных купюр музей располагает металлическими шкафами. Денежные единицы хранятся в бумажных конвертах, собранных в картонных коробках.

Необходимо отметить, что большая заслуга в пополнении денежной коллекции Национального музея им. Алдан-Маадыр принадлежит школьникам, учителям и школьным музеям республики. В книгах поступлений хранятся записи о том, что это были дети и взрослые из сел Кочетово, Берт-Даг и Бояровка, из г. Кызыла, из Тоджинского района. Также уникальная коллекция денег обогащалась благодаря усилиям сотрудников музея, таких как Л. М. Салчак, М. Б. Кенин-Лопсан, которые в ходе научных экспедиций в районы привозили образцы монет и акша.

Благодаря коллекции музея мы имеем возможность своими глазами проследить историю денежной реформы и убедиться в реальности существования собственной национальной валюты у молодого тувинского государства.

\section{Тувинский торгово-промышленный банк - организатор финансово-денежной реформы ТНР}

Геополитическое положение Тувы, которая входила в круг политических и экономических интересов двух соседних империй - Китая и России, - способствовало распространению валют этих государств в денежном обмене края. В обращении были золотые и серебряные рубли, китайские ланы и гамбургское серебро (Аранчын, 1982: 20). Поэтому в переходный период денежной реформы в 1921-1935 гг. в качестве денежных единиц в ТНР использовались китайские ланы, монгольские тугрики, царские дореволюционные рубли и советский рубль.

Главным учреждением, осуществлявшим финансовую политику ТНР, был Тувинский торгово-промышленный банк (Тувинбанк), учрежденный по соглашению с Госбанком СССР 25 июля 1925 г. (Копеел, 1981: 83). Как указывают историки, «банк сыграл решающую роль в укреплении экономического положения республики, содействовал развитию всех отраслей народного хозяйства, способствовал укреплению денежного обращения в стране» (История Тувы, 2007: 176).

${ }^{1}$ Акша - общетюркское слово, означающее деньги, монеты, финансы (Татаринцев 2015: 84). 
НОВЫЕ ИССЛЕДОВАНИЯ ТУВЫ

Www.nit.tuva.asia

Государственный и другие банки СССР предоставляли Тувинбанку долгосрочные кредиты на значительные суммы для покупки машин, оборудования, на дорожное и коммунальное строительство. Подавляющая сумма денежных средств, выданных на развитие сельского хозяйства ТНР, являлись безвозвратными кредитами (Иезуитов, 1956: 120).

После того, как в 1924 г. в Советском Союзе денежные знаки, выпускавшиеся в Закавказье, Средней Азии, Дальнем Востоке, были заменены на общесоюзные деньги: червонцы, казначейские билеты и разменную монету (Денежное обращение ..., 1965: 63), при поддержке СССР Тувинская Народная Республика в середине 1920 - начале 1930-х гг. провела ряд реформ, позволивших в 1935 г. ввести акша тувинскую национальную валюту. Акша 1935 и 1940 гг. (было только два выпуска) являлась денежной единицей Тувы в течение девяти лет.

\section{Тувинские акша}

Первая коллекция тувинских денег, принятая музеем в 1954 г., была одной из полных, так как в ней были купюры всех достоинств: 1, 3, 5, 10, 25 акша 1935 и 1940 годов выпуска.

Так выглядит 1 акша 1935 г. (фото 1).

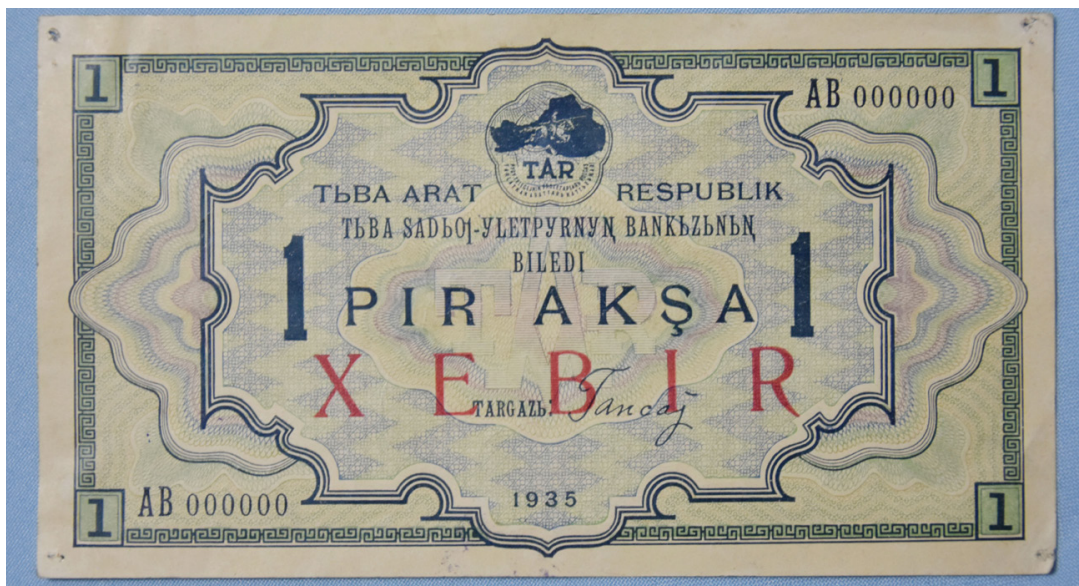

Фото 1.1 акша 1935 г., лицевая сторона, образец. НМ РТ, Ф. 10, ДПИ, шкаф № 15, полка 13, коробка 1.

Фото А. Д. Куулар, 2018 г.

Photo 1.1 aksha (1935 issue), obverse, sample. National Museum, Republic of Tuva, F.10, DPI, Cab.15, Shelf 13, Box 1. Photo by A. D. Kuular, 2018.

Ниже приводим фотографию 1 акша 1940 года (фото 2).

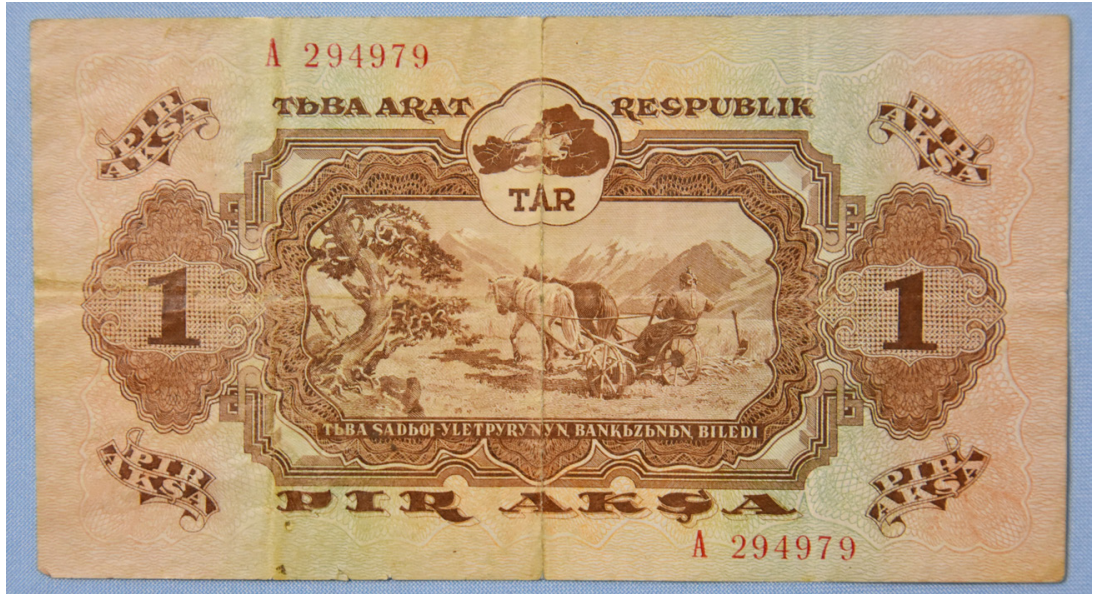

Фото 2. 1 акша 1940 г., лицевая сторона. НМ РТ, Ф. 10, ДПИ, шкаф № 15, полка 13, коробка 1. Фото А. Д. Куулар, 2018 г.

Photo 2.1 aksha (1940 issue), obverse. National Museum, Republic of Tuva, F.10, DPI, Cab.15, Shelf 13, Box 1. Photo by A. D. Kuular, 2018. 
На оборотной стороне 1 акша 1940 г. написано: «Банковский билет обеспечивается золотом, драгоценными металлами и другими активами Тувинского торгово-промышленного банка» (фото 3).

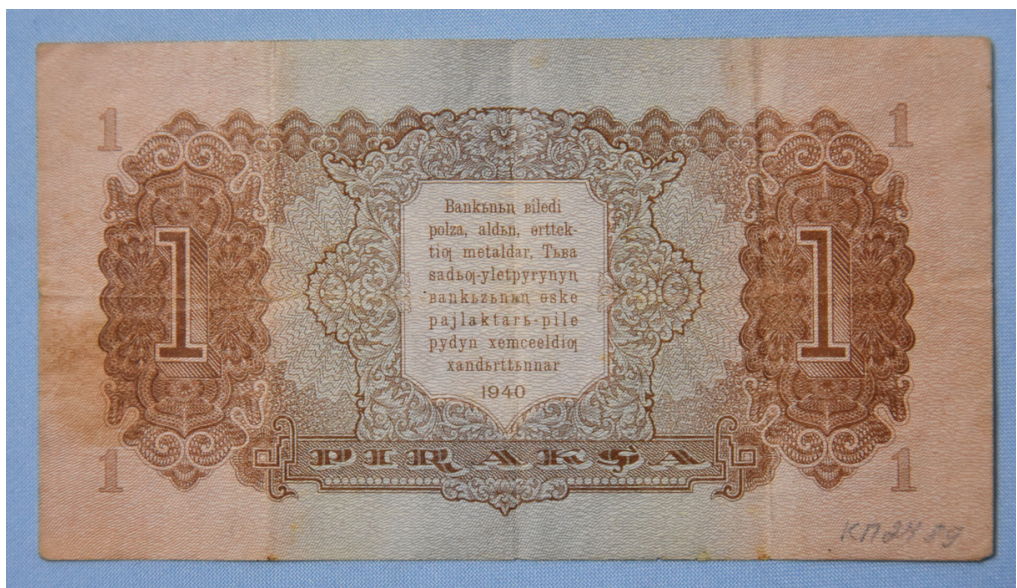

Фото 3. 1 акша 1940 2., оборотная сторона. НМ РТ, Ф. 10, ДПИ, шкаф №15, полка 13, коробка 1.

Фото А. Д. Куулар, 2018 г.

Photo 3. 1 aksha (1940 issue), reverse. National Museum, Republic of Tuva, F.10, DPI, Cab.15, Shelf 13, Box 1. Photo by A. D. Kuular, 2018.

Удивительным является тот факт, что среди них были купюры 1935 г. (фото 4).

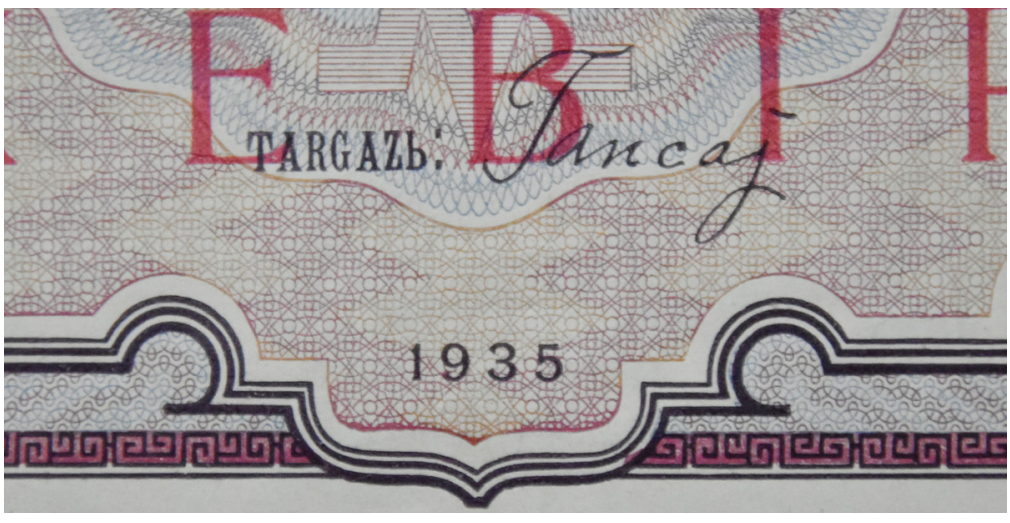

Фото 4. Фрагмент купюры 1935 г. с подписью Председателя Тувинбанка Оюна Танчая на латинской графике: «Тапсај». НМ РТ, Ф.10, ДПИ, шкаф №15, полка 13, коробка 1. Фото А. Д. Куулар, 2018 г.

Photo 4. Fragment of a banknote (1935 issue) with a signature of Oyun Tanchay, Chairman of the Bank of Tuva. Signed in Latin script, «Tancaj». National Museum,

Republic of Tuva, F.10, DPI, Cab.15, Shelf 13, Box 1. Photo by A. D. Kuular, 2018.

Эти деньги изымались из обихода, так как на них стояла подпись репрессированного в 1938 г. руководителя Тувинбанка Оюна Танчая Чыранды-оглу (фото 5).

Как писал К. А. Бичелдей, «дилемма была очень непростая: на всех банкнотах его имя убрать просто невозможно, а пользоваться валютой за подписью расстрелянного «контрреволюционера» было и вовсе нельзя. Проблему пришлось решать самым радикальным образом - срочно заказали выпуск новых денег ТНР в СССР» (Бичелдей, 2009: 23). Денежные купюры с подписью Оюна Танчая, «врага народа», необходимо было изъять из оборота и заменить их новым выпуском. Образно выражаясь, денежные купюры 1935 г. выпуска подверглись репрессиям, как и один из их создателей. На сегодняшний день в фондах музея имеются только банковские образцы акша 1935 года выпуска.

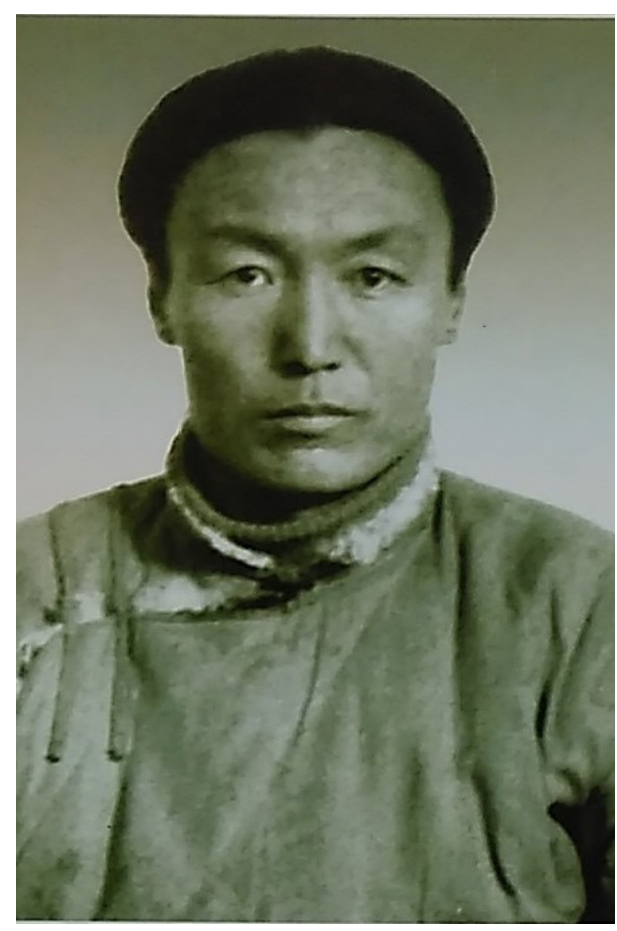

Фото 5. Оюн Танчай Чыранды-оглу 1883-1938 г2.) (Государственный Архив РТ, Ф. 1, оп. 2, д. 232, л. 1).

Photo 5. Oyun Tanchay Chyrandy-Oglu (1883-1938) (State Archives of the Republic of Tuva, F.1, op.2, d. 232, l. 1) 
Образцы новых денежных знаков были утверждены в 1940 г. и заказ на печать размещен в СССР. «Банкноты тувинских денег второго, 1940 г. выпуска, отличаются от банкнот 1935 г. в целом своим «более благородным» видом - цветовая гамма их исполнения более яркая и насыщенная, в центре лицевой стороны появился рисунок, окаймляющие обе стороны узорчатый прямоугольник и центральная фигура банкноты 1935 г. исчезли, композиция узорчатых линий стала более согласованной с остальными элементами купюры» (Бичелдей, 2009: 24).

Второй выпуск акша находился в обращении около четырех с половиной лет.

\section{Тувинские монеты}

В 1955 г. в музее появились монеты ТНР образца 1934 г. в 3, 5, 10, 15 коп., принятые от семьи Фунтиковых Пелагеи Ефремовны и Давида Петровича.

На аверсе монет на тувинском языке на латинской графике написано их достоинство (фото 6).

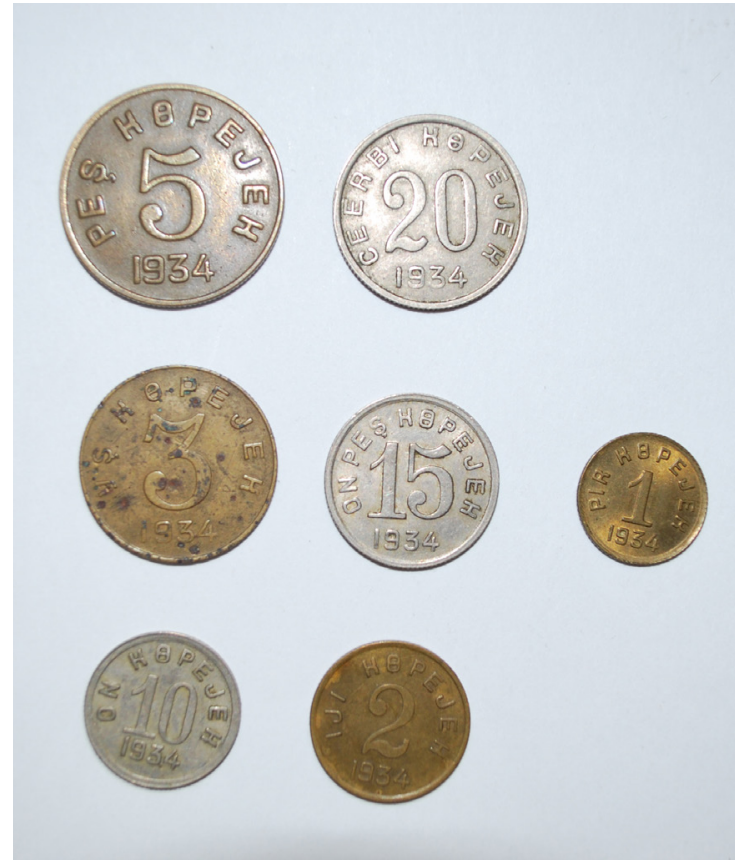

Фото 6. Аверс тувинских монет 1934 года выпуска, НМ РТ, Ф. 10, ДПИ, шкаф № 16, полка 4. Фото А. Д. Куулар, 2018 г.

Photo 6. Coins of Tuva (1934 issue), obverse. National Museum, Republic of Tuva, F.10, DPI, Cab.16, Shelf 14. Photo by A.D. Kuular, 2018.

с номиналами 1, 3, 5, 10 и 25 акша. Тувинская валюта 1935 г., как отмечает К. А. Бичелдей, представляет собой прямоугольную бумажную банкноту, напечатанную на специальной плотной бумаге хорошего качества, без водяных знаков, но с очень сложным узорным орнаментом основного рисунка и фонового оформления (Бичелдей, 2009: 23).

На оборотной стороне купюр на тувинском языке латинской графикой написано : «Банковский билет полностью обеспечивается золотом, драгоценными металлами, внешним серебром и другими ценностями Тувинского торгово-промышленного банка».
На реверсе монет стоит надпись: «Тувинский торгово-промышленный банк. Тувинская Аратская Республика» (фото 7).

По заказу Правительства ТНР Госзнак СССР на Монетном Дворе г. Ленинграда в 1934 г. отчеканил монеты тувинской национальной валюты с номиналами 1, 2, 3, $5,10,15$ и 20 копеек.

К. А. Бичелдей описал эти монеты: «Монеты номиналами 1, 2, 3 и 5 копеек отлиты из сплава желтоватого оттенка, а монеты номиналами 10, 15 и 20 копеек отлиты из никелевого сплава серебристо-светлого оттенка. Все монеты окаймлены ребром, покрыты зубчато-ребристым поперечным объемным рисунком. На всех монетах по аверсу использован единый способ барельефного выделения внутреннего ободка, а также цифрового и буквенного обозначения номиналов и года выпуска» (Бичелдей, 2009: 20).

Бумажные денежные знаки были напечатаны в 1935 г.

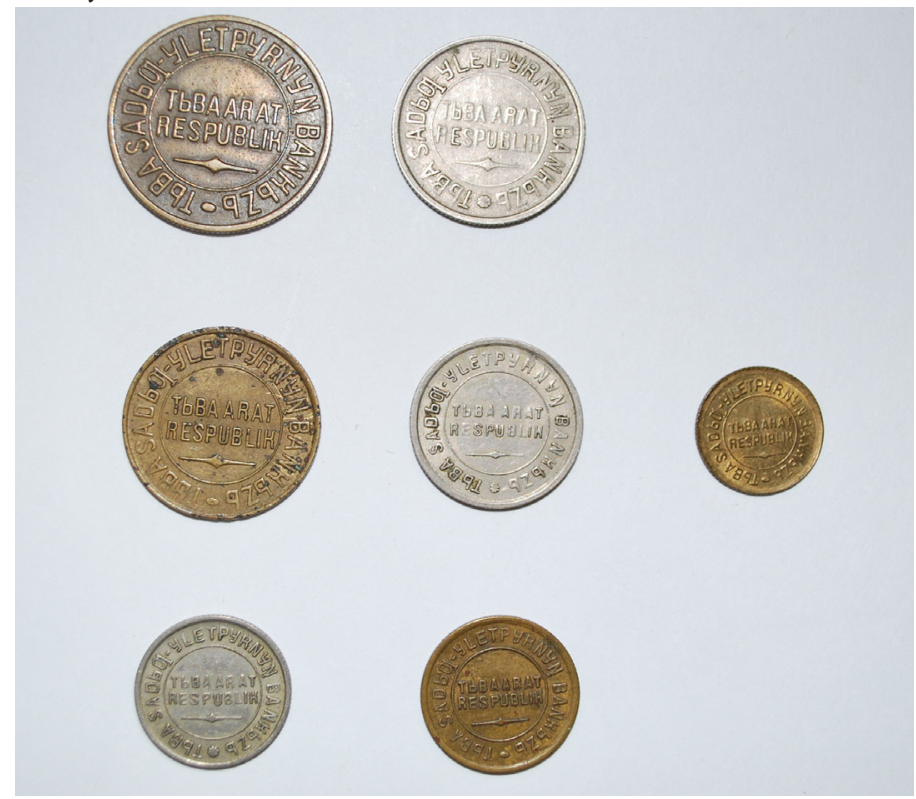

Фото 7. Реверс тувинских монет 1934 года выпуска, НМ РТ, Ф. 10, ДПИ, шкаф № 16, полка 4. Фото А. Д. Куулар, 2018 г.

Photo 7. Coins of Tuva (1934 issue), reverse. National Museum, Republic of Tuva, F.10, DPI, Cab.16, Shelf 4. Photo by A. D. Kuular, 2018. 


\section{Денежная коллекция С. К. Тока}

В 1956 г. фонды музея пополнились предметами личной коллекции Салчака Калбакхорековича Тока, партийного и государственного деятеля, бессменно возглавлявшим республику в период с 1932 по 1973 гг. С. Тока пополнил музейные фонды наряду с уже имевшимися образцами акша, бонами - денежными купюрами 1925, 1926, 1928 годов со штампом ТНР (фото 8).

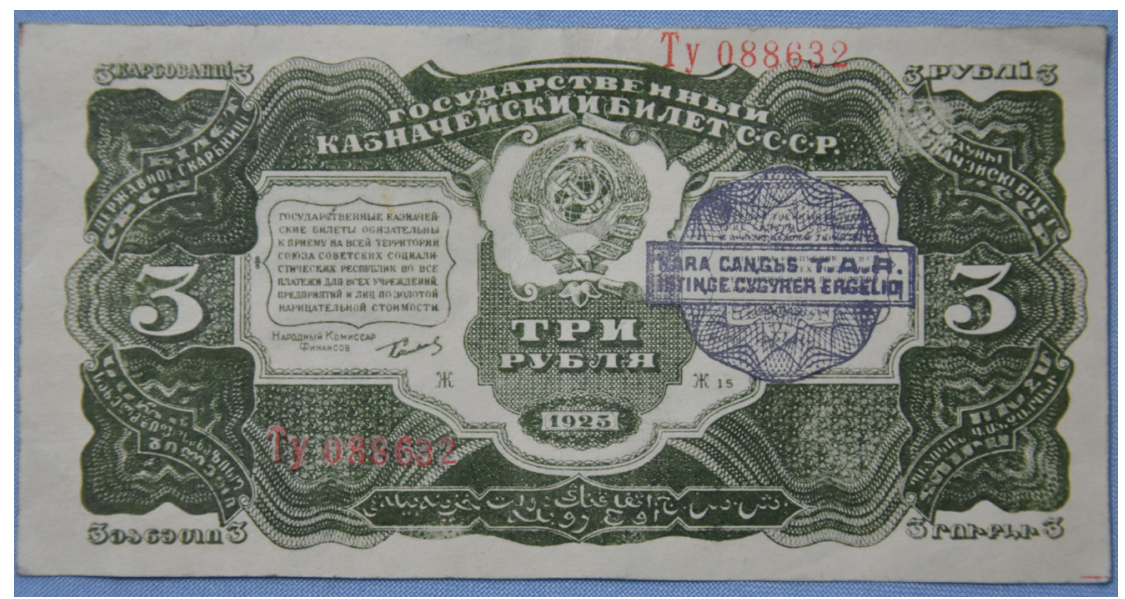

Фото 8. 3 рубля 1925 г., оборотная сторона. НМ РТ, Ф. 10, ДПИ, шкаф № 15, полка 13, коробка 1. Фото А. Д. Куулар, 2018 г.

Photo 8.3 roubles (1925 issue), reverse. National Museum, Republic of Tuva, F.10, DPI, Cab.15, Shelf 13, Box 1. Photo by A. D. Kuular, 2018.

В декабре 1933 г., еще до создания собственной валюты, Советом Министров и Президиумом Малого Хурала ТНР было принято постановление о выпуске в обращение штемпелеванных денежных знаков. Для этого использовали советские рубли номиналами в 1 рубль 1928 г., 3 и 5 рублей 1925 г. и билеты Государственного банка в 1 червонец 1926 г. и 2 червонца 1928 г. «На лицевой стороне этих знаков помещена надпечатка в форме овальной, слегка граненой, виньетки с орнаментом, на котором в прямоугольной рамке приведен текст в две строки на тувинском языке, напечатанный буквами латинского алфавита» (Ананьин, Рогов, 2014: 135). Штапм «Kapa cangbs T.A.R. istinge cygyrer ergelig»переводится на русский язык как «Имеет право хождения только на территории ТНР». Эти денежные знаки были в обращении до 1935 г., когда появилась тувинская акша.

\section{Боны Тувинской Народной Республики}

В 1959 г. в дар музею от учеников 6-го класса поступили государственные кредитные билеты царской России 1898 г. - 1 руб., 1905 г. -3 руб., 1909 г. -5 руб. и 10 руб. Эти деньги являются свидетельством денежной реформы Министерства финансов ТНР 1923 г. Правительство выпустило боны, предназначенные для выплаты зарплаты служащим (Тульчинский, 1961: 274). По мнению А. Я. Ананьина и Г. И. Рогова, это были дореволюционные денежные знаки царской России с надпечаткой, выполненной на старомонгольском и русском языках. Надпечатка была сделана на оборотной стороне кредитных билетов достоинством в

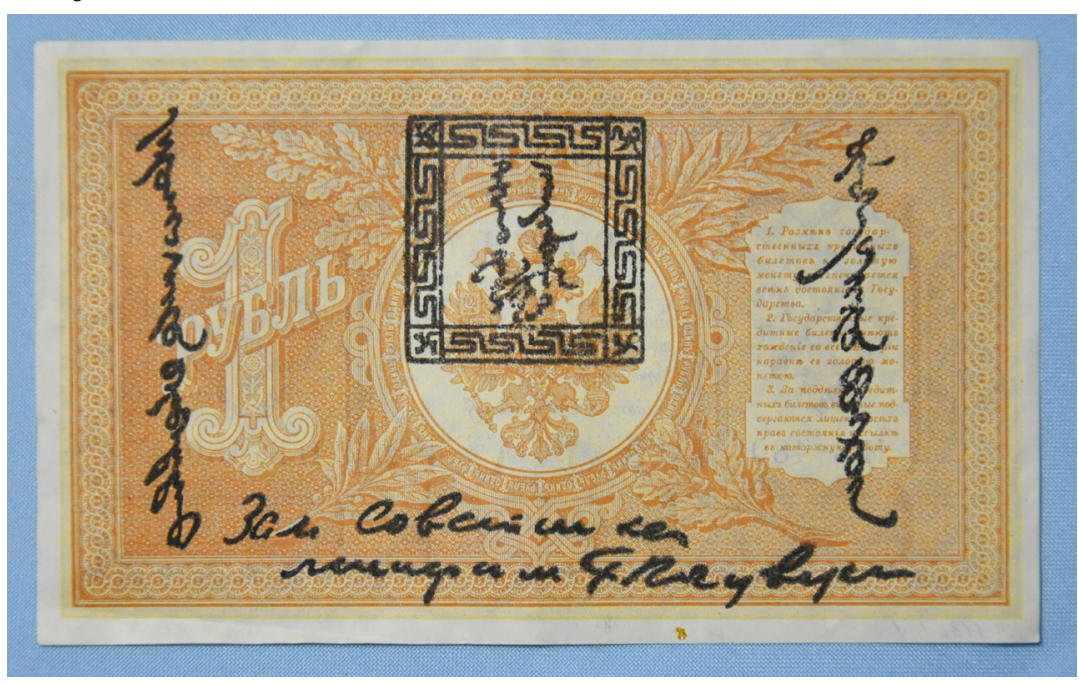

Фото 9.1 рубль, 1898 г., оборотная сторона. НМ РТ, Ф. 10, ДПИ, шкаф № 15, полка 13, коробка 1. Фото А. Д. Куулар, 2018 г.

Photo 9. 1 rouble banknote (1898 issue), reverse. National Museum, Republic of Tuva, F.10, DPI, Cab.15, Shelf 13, Box 1. Photo by A.D. Kuular, 2018. 
1 рубль 1898 г., 3 рубля 1905 г., 5 рублей 1909 г. и 10 рублей 1909 г. (Ананьин, Рогов, 2014: 134) (фото 9). А так выглядит лицевая сторона купюры 1 рубля 1898 г. (фото 10).

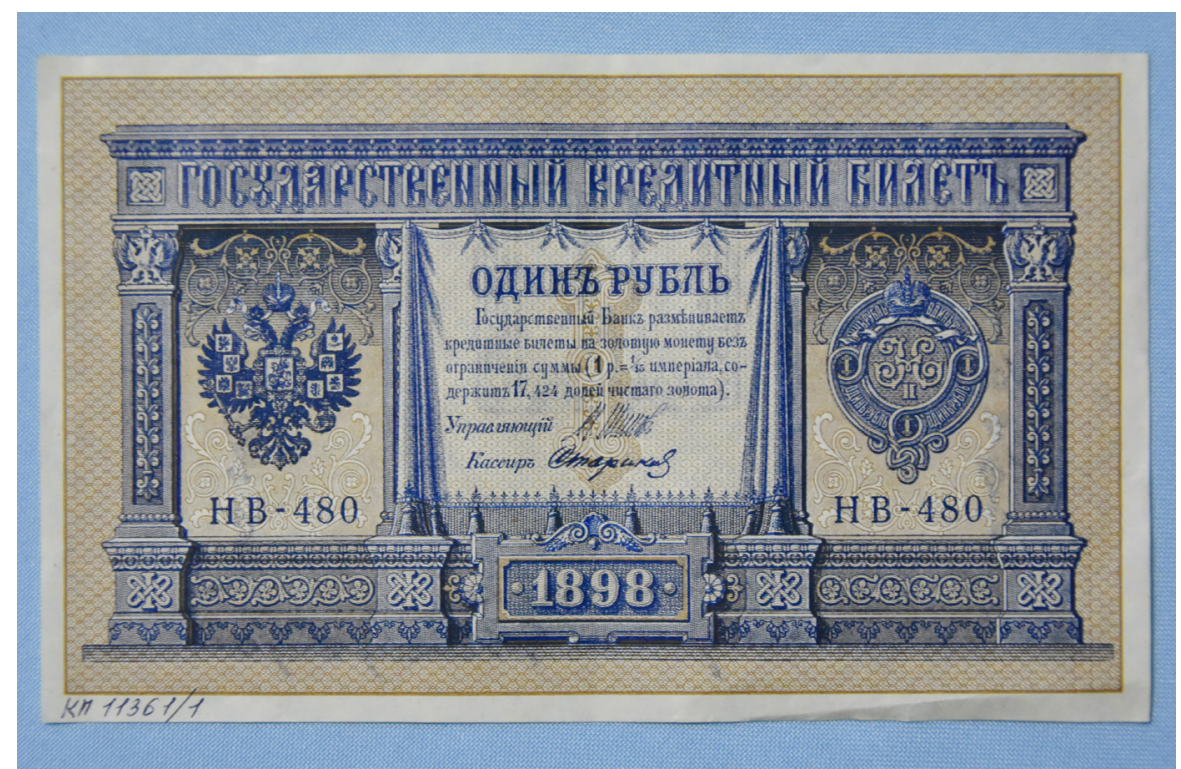

Фото 10. 1 рубль, 1898 г., лицевая сторона. НМ РТ, Ф. 10, ДПИ, шкаф № 15, полка 13, коробка 1. Фото А. Д. Куулар, 2018 г.

Photo 10. 1 rouble banknote (1898 issue), obverse. National Museum, Republic of Tuva, F.10, DPI, Cab.15, Shelf 13, Box 1. Photo by A. D. Kuular, 2018.

На оборотной стороне этих купюр стоит квадратная печать с надписью на старомонгольской письменности: «Танну Тува ун Санг ун йамун тамга» (на тувинский язык переводится как «Таңды Тываның Саңының яамызының таңмазы»; перевод на русский - «Печать Министерства финансов Танну Тувы»).

Надпись слева на старомонгольском: «Ёронхий сайд Буянбаторху» (по-тувински - «Эреңгей сайыт Буян-Бадыргы»; на русском языке - «Премьер-министр Буян-Бадыргы»).

Надпись справа на старомонгольском: «Төлұге сайд Пунцук» (по-тувински - «Төлээ сайыт Пунцук»; на русском языке - «Заместитель министра Пунцук»).

Надпись внизу на русском языке: «Зам. Советника Минфина ...»- подпись кириллицей не разборчива.

Купюра в 3 рубля 1905 г. с оборотной стороны (фото 11). Ниже фотографии этой же купюры с лицевой стороны (фото 12).

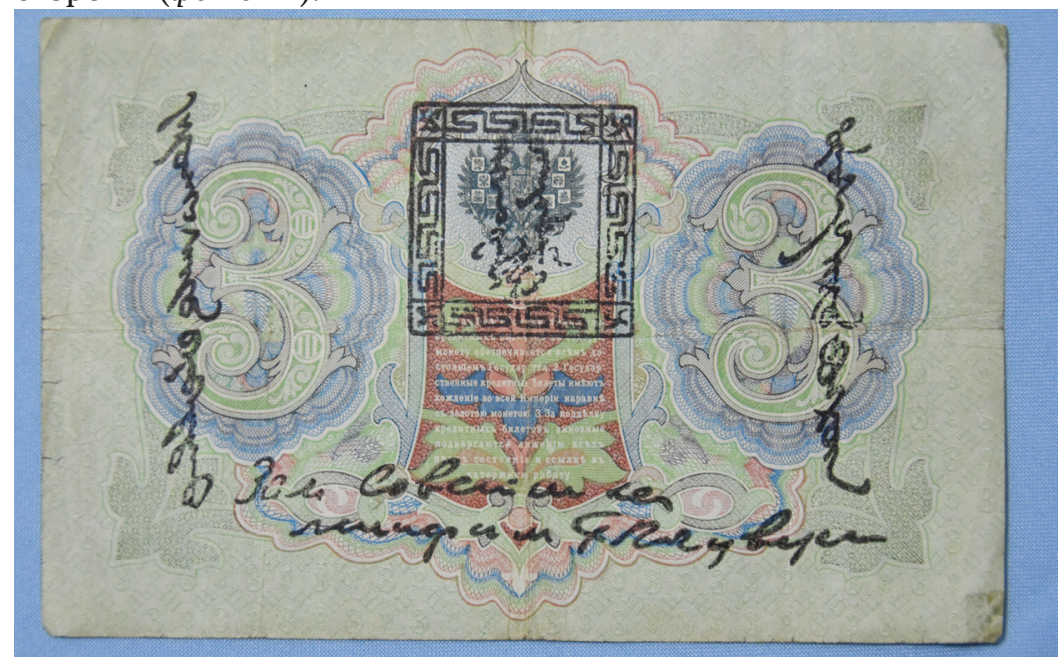

Фото 11. 3 рубля 1905 г., оборотная сторона. НМ РТ, Ф. 10, ДПИ, шкаф № 15, полка 13, коробка 1. Фото А. Д. Куулар, 2018 г.

Photo 11. 3 roubles banknote (1905 issue), reverse. National Museum, Republic of Tuva, F.10, DPI, Cab.15, Shelf 13, Box 1. Photo by A. D. Kuular, 2018.
Новые явления в экономической жизни республики, в том числе проведение денежной реформы, получили отражение в государственных документах. Так, например, в 1942 г. были разработаны «Правила по денежному обращению в ТНР» (Харунова, 2018: Электр. ресурс). Укрепление товарно-денежных отношений в республике и становление финансовой системы способствовало появлению новых терминов и понятий, отражавших, в том числе, результаты денежной реформы в государстве. Например, в обиход вошли такие понятия, как акша эргилдези (денежный оборот); күр хөреңзизи (государственные денежные средства); банкыда агар сан (текущий счет 
в банке) и др. Их появление способствовало активному развитию делового стиля тувинского языка, который значительно обогатился экономической составляющей.

\section{Заключение}

Таким образом, с тех пор, как в фонды Национального музея поступили первые образцы денег и монет ТНР, прошло около 70 лет. С каждым годом их ценность только растет. Обусловлено это тем, что их невозможно воспроизвести, растет их возраст, а значит - уникальность и ценность, как предметов яркой политической и экономической истории Тувинской Народной Республики. Выпуск собственной валюты, официально именуемой «билетами Министерства финансов

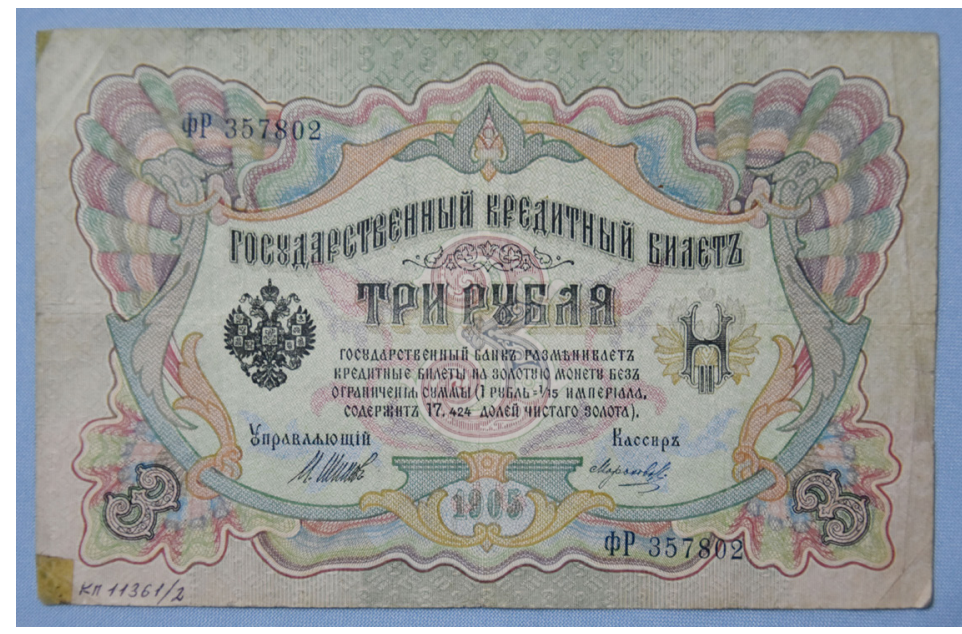

Фото 12.3 рубля 1905 г., лицевая сторона. НМ РТ, Ф. 10, ДПИ, шкаф № 15, полка 13, коробка 1. Фото А. Д. Куулар, 2018 г.

Photo 12.3 roubles banknote (1905 issue), obverse. National Museum, Republic of Tuva, F.10, DPI, Cab.15, Shelf 13, Box 1. Photo by A. D. Kuular, 2018. ТНР», по факту, явился атрибутом госу-

дарственного суверенитета ТНР. С их выпуском окончательно был вытеснен натуральный обмен, укрепилась база расчетной системы, налогообложения, госбюджета, что стало серьезным фактором экономического развития молодой республики.

Денежная коллекция музея является ценным источником по истории Тувы, благодаря которой мы можем получить достоверную информацию о специфике становления финансовой системы ТНР, влиянии СССР на социально-экономическое развитие республики, о политических деятелях, успешно осуществивших денежную реформу.

Сегодня тувинский акша бесспорно являются одним из уникальных явлений в мире нумизматики. И задача современников сохранить это мировое историческое наследие для следующих поколений.

\section{Благодарности}

Выражаем глубокую благодарность за содействие в подготовке данной статьи директору Национального музея им. Алдан-Маадыр РТ, д. ф. н. Каадыр-оолу Алексеевичу Бичелдею и фотографу музея Айдане Даниловне Куулар.

\section{СПИСОК ЛИТЕРАТУРЫ}

Ананьин, А. Я., Рогов, Г. И. (2014) Денежные знаки Тувы // Антиквариат, предметы искусства и коллекционирования. № 9 (119). С. 134-143.

Аранчын, Ю. Л. (1982) Исторический путь тувинского народа к социализму. Новосибирск: Наука. 337 с.

Бичелдей, К. А. (2009) Денежная реформа ТНР 1925-1940 гг. - банкноты и монеты Тувы как предмет нумизматики (по фондовым материалам Национального музея Республики Тыва) // Наследие народов Центральной Азии и сопредельных территорий: изучение, сохранение и использование. Материалы научно-практической конференции, г. Кызыл, 9-10 сентября 2009 г.: в 2-х ч. / сост. У. Б. Нурзат. Кызыл: КЦО «Аныяк». Ч. 1. 199 с. С. 18-26.

Денежное обращение и кредит СССР (1986) / под ред. В. С. Геращенко. М. : Изд-во «Финансы». 244 с.

Иезуитов, В. М. (1956) От Тувы феодальной к Туве социалистической. Кызыл: Тувинское книжное издательство. $208 \mathrm{c.}$

История Тувы (2007): в 3 т. / под общ. ред. В. А. Ламина. Новосибирск : Наука. Т. 2. 430 с.

Копеел, В.А. (1981) Деньги и денежное обращение в период ТНР // По пути Великого Октября. К 60-летию Народной революции в Туве / отв. ред. Ю. Л. Аранчын. Кызыл: Тувинское книжное издательство. 156 с. С. 81-89.

Татаринцев, Б.И.(2015) Этимологический словарь тувинского языка: в 4 т. Абакан : 000 «Кооператив «Журналист». T. $1.398 \mathrm{c}$.

Тульчинский, Л. И.(1961)К вопросу о зарождении и развитии финасово-кредитной системы в Туве (1921-1944 гг.) // Ученые записки. Выпуск IX. Кызыл : Типография управления культуры. С. 269-274. 
Харунова, М. М.-Б. (2018) Экономические термины в документах Тувинской Народной Республики (1921-1944 гг.) [Электронный ресурс]//Новые исследования Тувы. № 2.URL: https://nit.tuva.asia/nit/article/view/775 (дата обращения: 12.01.2019.). DOI: $10.25178 /$ nit.2018.2.9

Дата поступления: 01.03.2019 г.

\section{REFERENS}

Anan'in, A. Ya. and Rogov, G. I. (2014). Denezhnye znaki Tuvy [Monetary Units of Tuva]. Antikvariat, predmety iskusstva $i$ kollektsionirovaniia, no. 9 (119), pp. 134-143. (In Russ.).

Aranchyn, Iu. L. (1982) Istoricheskii put' tuvinskogo naroda $k$ sotsializmu [The historical path of the Tuvan people to Socialism]. Novosibirsk, Nauka. 337 p. (In Russ.).

Bicheldei, K. A. (2009) Denezhnaia reforma TNR 1925-1940 gg. - banknoty i monety Tuvy kak predmet numizmatiki (po fondovym materialam Natsional'nogo muzeia Respubliki Tyva) [The monetary reform of the People's Republic of Tuva, 19251944: banknotes and coins of Tuva as a subject of numismatics in the collections of the National Museum of the Republic of Tuva)]. In: Nasledie narodov Tsentral'noi Azii i sopredel'nykh territorii: izuchenie, sokhranenie i ispol'zovanie [Heritage of the peoples of Central Asia and adjacent territories: research, preservation and use] (September 9-10, 2009, Kyzyl): in 2 vol. / ed. by U. B. Nurzat. Kyzyl, KTSO «Anyiak». Vol. 1.199 p. Pp. 18-26. (In Russ).

Denezhnoe obrashchenie i kredit SSSR [Money circulation and credit facilities in the USSR] (1986) / ed. by V. S. Gerashchenko. Moscow, Finansy Publ. 244 p. (In Russ.).

Iezuitov, V. M. (1956) Ot Tuvy feodal'noi k Tuve sotsialisticheskoi [From feudal Tuva to Socialist Tuva]. Kyzyl, Tuvan book publ. 208 p. (In Russ.).

Istoriia Tuvy [The History of Tuva] (2007): in 3 vol. / ed. by V. A. Lamin. Novosibirsk, Nauka Publ. Vol. 2. 430 p. (In Russ).

Kopeel, V. A. (1981) Den'gi i denezhnoe obrashchenie v period TNR [Money and money circulation in the PRT]. In: Po puti Velikogo Oktyabrya. K 60-letiyu Narodnoi revolyutsii v Tuve [In the footsteps of the Great October. Dedicated to the 60th Anniversary of People's Revolution in Tuva]. Kyzyl, Tuvan book publ. 156 p. Pp. 81-89. (In Russ.).

Tatarintsev, B. I. (2015). Etimologicheskii slovar' tuvinskogo yazyka [An etymological dictionary of the Tuvan language]: in 4 vols. Abakan, OOO Kooperativ «Zhurnalist». Vol. 1. 398 p. (In Russ.).

Tul'chinskii, L. I. (1961). K voprosu o zarozhdenii i razvitii finasovo-kreditnoj sistemy v Tuve (1921-1944 gg.). [On the rise and development of the system of finance and credit in Tuva, 1921-1944]. Uchenye zapiski. Vol. IX. Kyzyl, Tipografiya upravleniya kul'tury. Pp. 269-274. (In Russ.).

Kharunova, M. M.-B. (2018) Ekonomicheskii terminy v dokumentakh Tuvinskoi Narodnoi Respubliki (1921-1944 gg.) [Economic terminology in the documents of the People's Republic of Tuva (1921-1944)]. The New Research of Tuva, no. 2 [online] Available at: https://nit.tuva.asia/ nit/article/view/775 (access date: 12.01.2019). DOI: 10.25178/nit.2018.2.9 (In Russ.). 